入を多くし燃橈性の改善につとめている。

6. 発生器上部チェンカの損耗が著しい。本法に特け るがごときガスの流れによる操作を探用する時は， 該部の急激な溫度变化は避け難く，ためにスポーリ ングは相当なるのである。現在 $90 \%$ シリコンカーバ イド栔瓦を使用し，2力月余の操業に耐兄，今な特 使用している。この点に関しては，チェッカ煉瓦の 品質と積方に影響せられるから種々の揀瓦について 武験を行つている。

\section{VII 結 語}

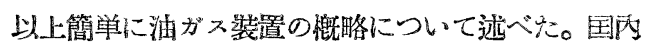
最初の裝置であつて多くの困難が予想せられたが。現 在な和種々の閭題を残しているるのの此較的順調に操 業を続けており，ガス事業に括ける有力な補給裝置と しての役割を果している。需給面に揓りる夏冬の負荷 の美翼は年々增大寸る傾向にあるから，その將来性も 犬きいと考劣ている。

本㼭置の未解決問題として，生成タールの合理的㚾
理呿よびその利用と，発生器チェッカの問題などがあ 3。 な法ガス分析值にみるごとく，エチレン，プロピレ ンの含有率が高くこれらの有效な回收方法を考究中た ある。精密分析の結果は,

$\begin{array}{lc}\left(\mathrm{CO}_{2} \text { free basis }\right) & \\ \text { Non-condensible } & 34 \% \\ \mathrm{CH}_{4} & 26.7, \\ \mathrm{C}_{2} \mathrm{H}_{4} & 23.2, \\ \mathrm{C}_{2} \mathrm{H}_{6} & 4.5 \% \\ \mathrm{C}_{3} \mathrm{H}_{6} & 7.4 \% \\ { }_{n}-\mathrm{C}_{4} \mathrm{H}_{8} i-\mathrm{C}_{4} \mathrm{H}_{8}, & 3.4, \\ \mathrm{C}_{5} \text { group } & 0.8,\end{array}$

で有用なェチレンが $20 \%$ を越え，この方面の利用浮 展がガスの燃燒性の改善とともに，大きな期待元持た れている。

今後の本琶置の隻步発展のために大方の御助力を党 引次第である。

\title{
On the Manufacture of Oil-Gas
}

\author{
By Saburo Tanaka \\ (Tokyo Gas Co. Ltd.)
}

\begin{abstract}
SYNOPSIS :- To meet the postwar increase of town gas consumption, new coke-ovens and producer gas ovens have been installed. However, meanwhile, the remarkable seasonal variations of the consumption made those installations uneconomical. The Tokyo Gas Co. has solved the situaton by the oil-gas process which produces gases with much higher calorific value from simpler installation. The new devices in the Senjyu Factory were described with a satisfactory result.
\end{abstract}

\section{正誤 訂 正 表}

前号 (第32烤第316号) の水出政吉氏卷頭言中下記のごとく言正致します。 429頁の12 13行目の44億7,000余万の次に「bb1 即ち 7 億1,000万余」が大る。 